\title{
Trends in Production, Procurement of Milk by Co-Operative Societies in Kerala
}

\section{OPEN ACCESS}

Manuscript ID:

ASH-2021-09013833

Volume: 9

Issue: 1

Month: July

Year: 2021

P-ISSN: 2321-788X

E-ISSN: 2582-0397

Received: 13.03.2021

Accepted: 20.05.2021

Published: 01.07.2021

Citation:

Nimisha, M., and

P. Shanmugam. "Trends in

Production, Procurement

of Milk by Co-Operative

Societies in Kerala."

Shanlax International

Journal of Arts, Science

and Humanities, vol. 9,

no. 1, 2021, pp. 119-124.

DOI:

https://doi.org/10.34293/

sijash.v9i1.3833

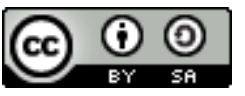

This work is licensed under a Creative Commons Attribution-ShareAlike 4.0 International License

\author{
M. Nimisha \\ Ph. D. Research Scholar, Department of Economics \\ Bharathiar University, Coimbatore, Tamil Nadu, India
}

\section{P. Shanmugam}

Assistant Professor of Economics, Bharathiar University, Coimbatore, Tamil Nadu, India

\begin{abstract}
Dairy sector has great contribution to the GDP of the country has come from the milk dairy cooperative sector. Milk and milk products are perhaps one of the very few consumption items common in all cultures around the world. Indian dairy Co-operative Societies sector contributes the large share in agricultural gross domestic products. Presently there are around 70,000 village dairy cooperative societies across the country. The main aim of this paper is to analyses the performance of Milk procurement and sales by dairy co-operative societies in Kerala. The study based on secondary data has been collected from dairy co-operative society's annual reports and the period of study from 1995 to 2018 and 2018 to 2020, expressed that the procurement has shown an increasing trend throughout the state of Kerala.
\end{abstract}

Keywords: Dairy co-operative societies, Milk procurement, Milk sales

\section{Introduction}

The Dairy Co-operative Societies started in India in the last decade of the $19^{\text {th }}$ Century. The golden era of Cooperative movement began after India had won freedom. "Within two decades of independence the membership of dairy cooperative societies had increased four times while the share capital and working capital also increased to a greater extent. Dairy Co-operative Societies were established in early eighties as an implementing agency of the operation flood II programme by National Dairy Development Board in the State of Kerala. Through these years dairy co-operative societies could accomplish spectacular progress in milk procurement and become a household name in Kerala". The goal of Dairy Co-operative Societies was the socio-economic progress of the dairy farmer through procuring, processing and marketing of milk and it works with the mission "farmers prosperity through consumer satisfaction" and it is also worthwhile to mention that Dairy Co-operative Societies is one the few cooperative societies which work in the true democratic lines of "of the farmer, by the farmer, for the farmer". By implementing various welfare measures utilizing the funds from Central, State and somehow own funds. Dairy Co-operative Societies were able to guarantee welfare and finical security to the dairy farmers of the state. The farmers were given remunerative price for the milk poured by them to the Dairy Co-operative society at regular intervals. Necessary inputs like cattle feed, mineral supplements, medical aid facilities were provided to the farmers through Dairy Co-operative Societies. Whenever the farmers faced difficulties, because of the rise in production cost, Dairy co-operative societies has taken bold steps to reduce the burden of farmers by revising the procurement price of milk. (Dairy Development Department, Kerala, 2018) Dairy Co-operative Societies was also committed to provide nutrition to lakhs 
of satisfied consumers of the state by providing quality milk constantly at affordable price by understanding the needs and desires of the consumers. (Dairy Development Department, Kerala, 2018)

\section{Review of Literature}

Prasad (2013) in the research article revealed that the organizational structure can improve the working condition of dairy co-operative societies .It was found that the design of the basic structure is somewhat different as it believes in the federal form of structure each unit is independent of each other. It is a popular belief that Dairy co-operative Societies are but Dairy Co-operative Societies Structure is a grand success. Dairy Co-operative Societies has an appropriate blend of policy makers, technology and a support system to the milk producers without disturbing their agro-economic system and ploughing back the profits, by materials and machines.

Periyasami (2006) said that the Procurement per litre of milk in India has been worked out to be the highest in the world. There was competitive advantage to increase India's global share of export in the dairy Co-operative societies. Since Indian dairy sector is one of the highest level subsidized Dairy Co-operative Societies in the world, it can therefore, afford to take a progressive in its position in world milk production. India became the world leader in milk production in 2001 with a production of 84 million tones.

Koshta and Chandrasekar (1999) analyzed milk Procurement in Raipur District in Maharashtra State in India. The Dairy Co-operative Societies institutions were selected through field survey method. The required and relevant data were gathered through structured questionnaire with the dairy Co-operative Societies interview technique. The study analyzed the procurement of milk, size of the Dairy Co-operative Societies of milk procurement, categories of milk animal possessed, productivity cost and returns of milk procurement and sale. The study suggested supplying cattle feed and arrangements for the milk procurement and dairy co-operative societies arrangements for the sale and procurement of milk. Further it is suggested the provision of such services and facilities at cheaper rate to the dairy co-operative Societies for enhancement of milk procurement.
Sangu (1995) revealed the members and nonmembers had 1.65 and 1.57 animals producing $4.69 \mathrm{kgs}$ and $4.40 \mathrm{kgs}$ average of milk per day respectively. The milk consumption per head was 340.77 grams and 285.52 grams by members and non-member households respectively.

\section{Objectives}

- The brief objective of the study was to analyze the performance of dairy co-operatives in terms of procurement and production.

\section{Methodology}

This paper used secondary data and they are obtained from official publications such as Livestock Census (Department of Animal Husbandry, Kerala), Statistical Abstract of Kerala State, Economic Survey of Kerala (Directorate of Economics and Statistics, Govt. of Kerala) and from related websites. The reference period of the study was from 1995 to 2020.

\section{Result and Discussions}

Table 1: World Milk Production

\begin{tabular}{|l|c|}
\hline Year & Total Milk Production (million tonnes) \\
\hline 1995 & 540.7 \\
\hline 1996 & 542.9 \\
\hline 1997 & 551.0 \\
\hline 1998 & 559.8 \\
\hline 1999 & 568.4 \\
\hline 2000 & 579.4 \\
\hline 2001 & 585.7 \\
\hline 2002 & 602.5 \\
\hline 2003 & 614.3 \\
\hline 2004 & 620.2 \\
\hline 2005 & 633.5 \\
\hline 2006 & 665.2 \\
\hline 2007 & 655.0 \\
\hline 2008 & 689.8 \\
\hline 2009 & 695.0 \\
\hline 2010 & 700.0 \\
\hline 2011 & 710.23 \\
\hline 2012 & 735.4 \\
\hline 2013 & 740.4 \\
\hline 2014 & 748.6 \\
\hline 2015 & 835.8 \\
\hline
\end{tabular}




\begin{tabular}{|c|c|}
\hline 2016 & 860.7 \\
\hline 2017 & 890.5 \\
\hline 2018 & 895.3 \\
\hline CGR & 2.21 \\
\hline
\end{tabular}

Source: Indian Dairyman, vol. 59, no. 11, 2007, p. 11 and Indian Journal of Dairy Science, vol. 63, no. 6, 2010, p. 492

Milk production in India is the world's largest; the total milk production in the world during 1995 to 2018 is depicted in Table 1. It was evident from the table that the world milk production over a period of 24 years has increased tremendously. There has been a fast growing trend in the world milk production over a period of 24 years. The share of the livestock sector out of India's agricultural sector 19952000, was increased to 2005-2011 and 2012-2018. India's dairy sector accounts for about highest of its livestock industry, making it an important sector in the country. During the reference period, the estimated Compound Growth Rate (CGR) of total milk production in the world was positive which was estimated to be 2.21 percent per annum.

The production and per capita availability of milk in India has been shown in table 2. It reveals that the milk production increased from 66.2 million tonnes in 1995-1996 to 112.1 million tonnes in 2009-2010. The per capita availability of milk also increased from
197 grams per day in $1995-1996$ to 263 grams per day in 2009-2010. The estimated Compound Growth Rate (CGR) for production and per capita availability of milk was $3.78 \& 1.98$ percent respectively.

Table 2: Production and per capita Availability of Milk in India

\begin{tabular}{|c|c|c|}
\hline Year & $\begin{array}{c}\text { Production } \\
\text { (in Million } \\
\text { Tonnes) }\end{array}$ & $\begin{array}{c}\text { Per capita } \\
\text { Availability } \\
\text { (grams / day) }\end{array}$ \\
\hline $1995-1996$ & 66.2 & 197 \\
\hline $1996-1997$ & 69.1 & 202 \\
\hline $1997-1998$ & 72.1 & 207 \\
\hline $1998-1999$ & 75.4 & 213 \\
\hline $1999-2000$ & 78.3 & 217 \\
\hline $2000-2001$ & 80.6 & 220 \\
\hline $2001-2002$ & 84.4 & 225 \\
\hline $2002-2003$ & 86.2 & 230 \\
\hline $2003-2004$ & 88.1 & 231 \\
\hline $2004-2005$ & 92.5 & 233 \\
\hline $2005-2006$ & 97.1 & 241 \\
\hline $2006-2007$ & 100.9 & 246 \\
\hline $2007-2008$ & 104.8 & 252 \\
\hline $2009-2010$ & 108.5 & 258 \\
\hline CGR & 3.78 & 1.98 \\
\hline
\end{tabular}

Source: Department of Animal Husbandry, Dairying and Fisheries, Government of India

Table 3: Volumes of Milk Procurement by Cooperatives and Number of Functional DCSs and their Trends

\begin{tabular}{|l|c|c|c|c|}
\hline & $\begin{array}{c}\text { Procurement } \\
\text { volume of milk } \\
\text { (TKgPD) in 2015 }\end{array}$ & $\begin{array}{c}\text { \% change in } \\
\text { procurement from } \\
\mathbf{2 0 1 1 - 2 0 1 5}\end{array}$ & $\begin{array}{c}\text { Number of } \\
\text { functional DCSs } \\
\text { in 2015 }\end{array}$ & $\begin{array}{c}\text { \% change in the } \\
\text { number of functional } \\
\text { DCSs from 2011-2015 }\end{array}$ \\
\hline Andhra Pradesh & 2,044 & $8 \%$ & 2748 & $5 \%$ \\
\hline Assam & 22 & $226 \%$ & 178 & $84 \%$ \\
\hline Bihar & 1,726 & $63 \%$ & 14,179 & $67 \%$ \\
\hline Chhattisgarh & 74 & $146 \%$ & 654 & $129 \%$ \\
\hline Goa & 66 & $61 \%$ & 176 & $2 \%$ \\
\hline Gujarat & 17,481 & $67 \%$ & 16,020 & $22 \%$ \\
\hline Haryana & 450 & $-16 \%$ & 3,3461 & $-13 \%$ \\
\hline Himachal Pradesh & 57 & $-16 \%$ & 442 & $-2 \%$ \\
\hline Jharkhand & 61 & $1194 \%$ & 46 & $21 \%$ \\
\hline Karnataka & 6480 & $52 \%$ & 13,287 & $15 \%$ \\
\hline Kerala & 1099 & $37 \%$ & 2892 & $5 \%$ \\
\hline Madhya Pradesh & 1029 & $43 \%$ & 6315 & $31 \%$ \\
\hline Maharashtra & 3646 & $16 \%$ & 11334 & $-9 \%$ \\
\hline
\end{tabular}


International Journal of Arts, Science and Humanities

\begin{tabular}{|l|c|c|c|c|}
\hline Nagaland & 3 & $64 \%$ & 30 & $0 \%$ \\
\hline Odisha & 526 & $75 \%$ & 3871 & $54 \%$ \\
\hline Punjab & 1392 & $25 \%$ & 6557 & $-3 \%$ \\
\hline Rajasthan & 2602 & $49 \%$ & 9,991 & $16 \%$ \\
\hline Sikkim & 27 & $111 \%$ & 323 & $65 \%$ \\
\hline Tamil Nadu & 3,040 & $41 \%$ & 8550 & $3 \%$ \\
\hline Tripura & 5 & $86 \%$ & 99 & $19 \%$ \\
\hline Uttar Pradesh & 322 & $-35 \%$ & 7169 & $-12 \%$ \\
\hline West Bengal & 160 & $-27 \%$ & 1528 & $13 \%$ \\
\hline
\end{tabular}

Source: NDDB 2015

Table 3 shows the volume of milk procurement by volumes of cooperatives and the number of functional DCSs and their trends for selected states. One can see that the procurement volume was steadily increasing during the study period in most of the states. Uttar Pradesh is one of the exceptions; its procurement volume has decreased by 35 percent in the last five years. One reason for this decrease was that increased competition with other private and cooperative dairy Co-operative Societies. The competition became especially intense when milk

(Gujarat dairy cooperative) started procuring milk in Uttar Pradesh after some unions in Gujarat set up their dairy plants there. The purchasing price of milk was higher than that of other private companies, and private firms were forced to increase their purchasing prices. Currently, the purchasing price of milk and some private firms is about 15 percent higher than that of the cooperative in Uttar Pradesh. Under these circumstances, many cooperative members started to sell their milk to other dairy companies that buy milk at higher prices.

Table 4: Procurement of Milk by Dairy Groups in Kerala

\begin{tabular}{|c|c|c|c|c|c|}
\hline \multirow{3}{*}{ District in Kerala } & \multicolumn{4}{|c|}{ Procurement of Milk by Dairy Groups } & \multirow{3}{*}{$\begin{array}{c}\text { Daily Increase } \\
(\%)\end{array}$} \\
\hline & \multicolumn{2}{|c|}{ 2016-2017 } & \multicolumn{2}{|c|}{ 2017-2018 } & \\
\hline & Total & Per Day (Itr) & Total & Per Day (ltr) & \\
\hline Thiruvananthapuram & 58178060 & 159392 & 69448711 & 190270 & $19.37 \%$ \\
\hline Kollam & 88969474 & 243752 & 98056256 & 268647 & $10.21 \%$ \\
\hline Pathanamthitta & 15147293 & 41499 & 17618211 & 48269 & $16.31 \%$ \\
\hline Alappuzha & 31809608 & 87150 & 38375154 & 105137 & $20.64 \%$ \\
\hline Kottayam & 29197957 & 79994 & 34370401 & 94166 & $17.71 \%$ \\
\hline Idukki & 58531054 & 160359 & 64140917 & 175729 & $9.58 \%$ \\
\hline Eranakulam & 41032391 & 112418 & 44425290 & 121713 & $8.26 \%$ \\
\hline Thrissur & 29851208 & 81784 & 3377791 & 92515 & $13.12 \%$ \\
\hline Palakkad & 41620849 & 114030 & 51093918 & 139983 & $22.7 \%$ \\
\hline Malappuram & 21211024 & 58112 & 2411109 & 66072 & $13.70 \%$ \\
\hline Kozhikode & 35907282 & 98376 & 38274280 & 104861 & $6.59 \%$ \\
\hline Wayanad & 74417711 & 203884 & 79671314 & 218278 & $7.06 \%$ \\
\hline Kannur & 47385432 & 129823 & 48263037 & 132227 & $1.85 \%$ \\
\hline Kasargod & 20775545 & 56919 & 22591145 & 61894 & $8.74 \%$ \\
\hline
\end{tabular}

Source: Dairy Development Report in Kerala (2018)

Palakkad district came first in the state with an increase of 22.76 percent in milk procurement through Dairy Co-operative Societies through implementation of Milk Shed Development Scheme and Ksheera Gramam Scheme. Alappuzha (20.64\%),

Thiruvananthapuram (19.37\%) and Kottayam $(17.72 \%)$ were ranked second, third and fourth respectively. The state average growth was 11.81 percent. Kannur district has the lowest daily increase. 
Table 5: Milk Procurement and Sales Trend in Kerala

\begin{tabular}{|c|c|c|}
\hline Year & $\begin{array}{c}\text { Procurement } \\
\text { (Ltr / Day) }\end{array}$ & $\begin{array}{c}\text { Milk Sales } \\
\text { (Ltr / Day) }\end{array}$ \\
\hline $2010-2011$ & 366272 & 392041 \\
\hline $2011-2012$ & 419053 & 411430 \\
\hline $2012-2013$ & 466461 & 422925 \\
\hline $2013-2014$ & 490620 & 423035 \\
\hline $2014-2015$ & 519824 & 449887 \\
\hline $2015-2016$ & 566268 & 475528 \\
\hline $2016-2017$ & 543214 & 492073 \\
\hline $2017-2018$ & 593605 & 488241 \\
\hline
\end{tabular}

\begin{tabular}{|c|c|c|}
\hline $2018-2019$ & 623496 & 495654 \\
\hline $2019-2020$ & 631126 & 505425 \\
\hline CGR & $\mathbf{5 . 7 8}$ & $\mathbf{2 . 2 6}$ \\
\hline
\end{tabular}

Source: Dairy Development Report in Kerala

Milk Procurement and sale prices in Kerala are showing a significant increase from year 2010-2020. Milk Procurement Sales in Kerala have increased significantly in the year 2019-2020. The estimated Compound Growth Rate (CGR) showed positive growth which was milk procurement and milk sales trend in Kerala was 5.78 (Milk Procurement) and 2.26 (Milk Sales) percent per annum.

Table 6: Milk Procurement and Input (P\&I) in Palakkad District

\begin{tabular}{|c|c|c|c|c|}
\hline Year & $\begin{array}{c}\text { Farmer Members } \\
\text { (APCOS) }\end{array}$ & $\begin{array}{c}\text { Milk } \\
\text { Suppliers }\end{array}$ & $\begin{array}{c}\text { Milk Proc. PER - } \\
\text { Supplier PER - Day }\end{array}$ & $\begin{array}{c}\text { Total Milk PROC: } \\
\text { APCOS Contribution }\end{array}$ \\
\hline $2008-2009$ & 262,327 & 73,893 & 5.26 & $92 \%$ \\
\hline $2009-2010$ & 278,410 & 79,039 & 4.94 & $96 \%$ \\
\hline $2010-2011$ & 291,812 & 79,159 & 5.02 & $94 \%$ \\
\hline $2011-2012$ & 293,908 & 80,293 & 6.33 & $96 \%$ \\
\hline $2012-2013$ & 306,831 & 84,325 & 6.48 & $96 \%$ \\
\hline $2013-2014$ & 319,219 & 84,107 & 6.36 & $96 \%$ \\
\hline $2014-2015$ & 332,753 & 87,901 & 6.84 & $96 \%$ \\
\hline $2015-2016$ & 342,938 & 92,353 & 6.99 & $97 \%$ \\
\hline $2016-2017$ & 360,828 & 92,719 & 6.70 & $98 \%$ \\
\hline $2017-2018$ & 353,192 & 88,937 & 7.87 & $98 \%$ \\
\hline CGR & $\mathbf{3 . 5 2}$ & $\mathbf{2 . 3 5}$ & $\mathbf{4 . 7 3}$ & $\mathbf{1 0 0}$ \\
\hline
\end{tabular}

Source: Dairy Development Report in Kerala

Palakkad district, is number one in milk production, has recorded a 98 percent increase in milk supply during 2016-17 to 2017-18. The Year with the lowest increase was 2008-2009. The farmer members (3.52), milk suppliers (2.35), milk procurement per supplier per day (4.73) and total milk PROC: APCOS Contribution (100) percent during the period of reference. estimated Compound Growth Rate (CGR) was

Table 7: Milk Pouring Details (2018 to 2019) (Palakkad District)

\begin{tabular}{|c|l|c|c|c|c|}
\hline $\begin{array}{c}\text { S. } \\
\text { No. }\end{array}$ & $\begin{array}{c}\text { Dairy Co-operative } \\
\text { Societies }\end{array}$ & $\begin{array}{c}\text { Total Number } \\
\text { of Beneficiaries }\end{array}$ & $\begin{array}{c}\text { Total Quantity } \\
\text { of Milk }\end{array}$ & $\begin{array}{c}\text { Total Amount } \\
\text { of Milk }\end{array}$ & $\begin{array}{c}\text { Total Days } \\
\text { (Per Year) }\end{array}$ \\
\hline 1 & Nalleppilly & 50,622 & $12,55,205$ & $43,55,1592$ & 87,486 \\
\hline 2 & Oluvampatta & 32,896 & $6,98,848.4$ & $25,71,9433$ & 68,009 \\
\hline 3 & Karinjalippallam & 19,110 & $7,24,275.8$ & $89,6462.5$ & 48,753 \\
\hline 4 & Kaundankalam & 17,391 & $6,02,956.3$ & $18,68,3343$ & 48,691 \\
\hline 5 & Arandappallam & 13,861 & 50,3475 & $15,25,4344$ & 60,590 \\
\hline 6 & Metukkada & 11,325 & $7,86,283$ & $32,25,0967$ & 54,750 \\
\hline 7 & Panniperunthala & 6,328 & $3,75,658$ & $13,63,2547.40$ & 40,880 \\
\hline & Total & $1,5,1,533$ & $1,03,73,3082$ & $14,99,88,688.9$ & $4,09,159$ \\
\hline
\end{tabular}

Source: Dairy Co-operative Society in Palakkad (2018-2019) 
Nalleppilly panchayath in Palakkad district is situated very near to Tamil Nadu. Today in this panchayath there were 24000 cows. This region has more grasslands and the climate is also favourable for dairy farming the availability of grass and straw are largely helpful for feeding the cattles. Availability of sufficient water is another favorable factor for dairy development as this panchayath near to Tamil Nadu of better breed cows are brought from there. The with the development milk dairy cooperative societies, Cattle rearing has become more profitable. The reason for the development of the economy in Nalleppilly Panchayath is agriculture and animal husbandry has an important role in the economy of any village without strong industrial background. Cattle rearing are an easy way to obtain income. Rearing of cow is the important livelihood of the majority people in the Nalleppilly panchayath. Milk societies help the farmers to gain more profit. There are seven milk societies in this panchayath. These milk societies are also called dairy cooperative society. These societies are working very effectively. Nalleppilly Dairy is the largest milk collection (12, $55,205)$ dairy co-operative society in a year. The lowest milk storage group is Panniperunthala dairy co-operative society (375658).From this list it can be seen that Nalleppilly dairy co-operative society is the largest milk collector out of the total $(1,03,73,3082)$ milk stocks.

\section{Conclusion}

The milk procurement has shown an increasing trend throughout the state of Kerala, which is a healthy sign for the future National Dairy Plan and help in increasing the milk production by the formation of new societies. The result also expressed that procurement \& sales of Milk Products has shown an increasing, trend throughout state of Kerala.

\section{References}

Basic Animal Husbandry \& Fisheries Statistics 2017.
Department of Animal Husbandry, Dairying and Fisheries.

Dairy Development Department Book, Kerala, 2018.

Dairy Development Report in Kerala, 2008-2018.

Dairy Development Report in Kerala, 2010-2020.

Dairy Development Report in Kerala, 2016-2018.

Department of Animal Husbandry and Dairying, Government of India, http://dahd.nic.in/

Directorate of Economics and Statistics, Government of Kerala, http://www.ecostat.kerala.gov.in.

Indian Dairyman, vol. 59, no. 11, 2007, P. 11

Indian Journal of Dairy Science, vol. 63, no. 6, 2010, P. 492.

Kerala State Animal Husbandry Department, https://ahd.kerala.gov.in.

Koshta, A.K., and Chandrasekar. "Economics of Production a Disposal of Fluid Milk in Members and Non-Members of Milk Cooperatives." Indian Co-operative Review, vol. 36, no. 4, pp.300-309.

Kumar, Ranjit, and A.K. Sharma. "Impact of Dairy Co-operatives on the Rural Economy in Nalanda District." Journal of Dairying Foods and Home Science, vol. 18, no. 2, 1999, pp. 92-97.

National Dairy Development Board Annual Report 2011-2015.

Periyasami, N. "Milk Production in India." Kisan World, vol. 33, no. 3, 2006, pp. 12-15.

Prasad, Ruchira. “A Case Study of Dairy Co-operative in India in Relation to Organizational Design and Operational Efficiency." International Journal of scientific \& Engineering Research, vol. 4, no. 1, 2013.

Sangu, K.F.S., "Impact of Dairy Cooperative Societies on Production, Consumption and Marketed Surplus of Milk." Indian Dairyman, vol. 47, no. 8, 1995, pp. 43-46.

Subramaniam, S. "Variation in Milk Yields - A Cross Breed and Agro Climatic Regions in Andhra Pradesh." The Asian Economic Review, vol. XI, no. 1, 1998, pp. 117-123.

\section{Author Details}

M. Nimisha, Ph.D. Research Scholar, Department of Economics, Bharathiar University, Coimbatore, India

Dr. P. Shanmugam, Assistant Professor, Department of Economics, Bharathiar University, Coimbatore, India 